\title{
Péguy, Bernanos et le monde moderne. Histoire et liberté, Actes reunis par Jean-François Durand
}

\section{Emanuele Kanceff}

\section{(2) OpenEdition}

12 Journals

\section{Edizione digitale}

URL: http://journals.openedition.org/studifrancesi/36667

DOI: 10.4000/studifrancesi.36667

ISSN: 2421-5856

\section{Editore}

Rosenberg \& Sellier

\section{Edizione cartacea}

Data di pubblicazione: 1 juillet 2005

Paginazione: 199

ISSN: 0039-2944

\section{Notizia bibliografica digitale}

Emanuele Kanceff, «Péguy, Bernanos et le monde moderne. Histoire et liberté, Actes reunis par JeanFrançois Durand», Studi Francesi [Online], 145 (XLIX | I) | 2005, online dal 30 novembre 2015, consultato il 21 avril 2021. URL: http://journals.openedition.org/studifrancesi/36667 ; DOI: https:// doi.org/10.4000/studifrancesi.36667

Questo documento è stato generato automaticamente il 21 avril 2021.

\section{(c) $(1) \ominus$}

Studi Francesi è distribuita con Licenza Creative Commons Attribuzione - Non commerciale - Non opere derivate 4.0 Internazionale. 


\title{
Péguy, Bernanos et le monde moderne. Histoire et liberté, Actes reunis par Jean-François Durand
}

\author{
Emanuele Kanceff
}

\section{NOTIZIA}

AV. vv., Péguy, Bernanos et le monde moderne. Histoire et liberté, Actes reunis par Jean-

François Durand, Paris, Honoré Champion, 2000, pp. 270.

1 Nonostante i molti lavori universitari e non che hanno illustrato l'opera dei due grandi scrittori in rapporto al mondo moderno, il tema è talmente fertile e ricco di riflessi che questa silloge di studi, frutto di un congresso scientifico tenutosi certamente all'Université Paul Valéry di Montpellier, ma sul quale non vengono date indicazioni, non solo è pienamente giustificata ma porta nuova linfa al pensiero critico sull'argomento.

2 L'opera è suddivisa in tre parti. Nella prima, sei saggi illustrano il dialogo reciproco tra $\mathrm{i}$ due scrittori, i rapporti con Bloch e Maritain, la ricezione dei Grands cimetières sous la lune.

3 La seconda parte, con quattro interventi, è riservata ai rapporti dei due scrittori con il mondo loro contemporaneo e la modernità. La terza infine, molto intensa, si occupa di storia e libertà, con efficaci riflessioni in cui non manca il problema dell'antisemitismo, o meglio la "question juive". 